\title{
Konstrukcja, charakter prawny i rodzaje składek na ubezpieczenie społeczne
}

Piotr Sidorowicz | Katedra Prawa Pracy, Wydział Prawa i Administracji, Uniwersytet Gdański

\section{Streszczenie}

Słowa kluczowe:

składki na ubezpieczenie społeczne, ustawa o systemie ubezpieczeń społecznych, Fundusz Ubezpieczeń Społecznych, publicznoprawny charakter składk

Opracowanie jest próbą nakreślenia konstrukcji, cech oraz rodzajów składek, które funkcjonują w ramach obowiązującego ustawodawstwa z zakresu ubezpieczeń społecznych.

Całość tekstu podzielona została na pięć części. Mają one samodzielny charakter, ale ich układ tworzy jedną całość, tak aby nadać odpowiedni walor poruszanego zagadnienia w odniesieniu do całości opracowania.

W pierwszej części, mającej charakter wstępu, rozróżniono ubezpieczenia społeczne od systemu zaopatrzenia społecznego poprzez pryzmat składek na ubezpieczenia, zwrócono także uwagę na istotę zabezpieczeń społecznych, w których usytuowane są ubezpieczenia społeczne. Druga część opracowania dotyczy funkcji, jakie pełnią składki na ubezpieczenie społeczne (w tym dostosowanie do odpowiedniego rodzaju ryzyka). Część trzecia artykułu - wobec braku definicji legalnej - obejmuje charakterystykę składki poprzez wskazanie jej istotnych cech. Kolejna część opracowania poświęcona została rodzajom składek na ubezpieczenie społeczne i ich wysokości; wymienia też podmioty zobowiązane do ich opłacania.

Ostatni rozdział niniejszego opracowania wskazuje postulaty de lege ferenda poprzez podjęcie próby odpowiedzi na pytanie o charakter składek na ubezpieczenie społeczne zarówno w oparciu o poglądy doktryny, jak i aktualne orzecznictwo sądowe.

\section{Legal character design and types of social insurance contribution}

Abstract

The study constitutes an attempt to outline the traits, legal character and types of the contributions that function within the binding legislation comprising the scope of the social insurances.

The whole text has been divided into five parts that are of an independent character, however their layout constitutes a whole so as to give an adequate value of the issue discussed with reference to the whole of the study. 
In the study attention was paid to the amendments in the legislation, which became the reason for a different outlook on the institution of the contribution functioning within the social insurances.

In the first part, having a character of an Introduction, a majority of attention was paid to differentiation of the social insurance from the social welfare system through the prism of the insurance contributions. Attention was also paid to the gist of social welfare in which the social insurances are situated in.

The second part of the study concerns trying to define the term of the social insurance contribution.

The following part of the study discusses the traits of the social insurance contribution, which have been indicated in the absence of the legal definition of the term.

The fourth part of the study concerns the characteristics of the contributions for particular social insurances, determining of the entities obliged to pay thereof and the amount of the social insurance contributions.

The last of the chapters has been dedicated to a trial of providing of an answer to the question as to the character of the social insurance contribution. It also contains a concise summary.

The terminology functioning in the framework of the issue addressed is impossible to discuss without the need to refer to the recognized authorities in the field of law, who worked out their own opinions in their rich scientific achievements.

From the practical point of view, the opinions expressed in the current judicial decisions are significant for the comprehensive compliment of functioning of the terminology. They influence operation of the institution in the public life, not only for the institutions applying the law, but also for the entity (individual) itself.

\section{Miejsce składek na ubezpieczenie w systemie zabezpieczenia społecznego}

Zabezpieczenie społeczne należy traktować w sposób wielostronny. Zajmuje ono istotne miejsce w systemie prawa ze względu na swój przedmiot. Kojarzone jest jako ochrona prawna i gwarancja bezpieczeństwa na wypadek zagrożenia (Jończyk 2003: 12), obejmuje bowiem szereg ustawowych gwarancji i świadczeń na wypadek wystąpienia określonego ryzyka socjalnego. Ma ono przy tym na względzie człowieka osobę fizyczną, a nie całą zbiorowość. Ochrona przed wystąpieniem ryzyka powoduje wiele obowiązków i uprawnień jednostki w ramach zabezpieczenia społecznego (Jończyk 2003: 23). Uregulowania odnoszące się do zabezpieczenia społecznego mają chronić jednostkę, czasem rodzinę, obejmują jednak całe społeczności w tym znaczeniu, że wspólny wysiłek podejmowany jest dla pokonania bądź złagodzenia zagrożenia (Jończyk 2003: 12). 
Punktem wyjścia dla rozważań dotyczących pojęcia zabezpieczenia społecznego jest art. 67 ust. 1 Konstytucji Rzeczpospolitej Polskiej. Wynika z niego, że obywatel ma prawo do zabezpieczenia społecznego w razie niezdolności do pracy ze względu na chorobę lub inwalidztwo oraz po osiągnięciu wieku emerytalnego. Zakres i formy zabezpieczenia społecznego określa ustawa, jest to zatem prawo obywatelskie. Wyjątkowo może być stosowane wobec nieobywateli, przy czym Konstytucja nie wypowiada się do konkretnej formy zabezpieczenia społecznego, pozostawiając swobodę do ich konkretyzacji woli ustawodawcy (Jończyk 2003: 32).

Konstytucja zakreśla w takim ujęciu pewne standardy ochrony, które mają zostać wypełnione poprzez tworzenie instytucji zabezpieczeniowych. Są to zatem gwarancje zabezpieczenia społecznego, jakie mają uzyskać obywatele, którzy w przypadku niezdolności do pracy lub dożycia wieku emerytalnego nie będą dalej aktywni zawodowo, ale w najwyższym z możliwych stopni nadal będą aktywnie uczestniczyć w życiu społecznym (występowanie ryzyka socjalnego). Jest to zatem ochrona, której brak powodowałby, że osoby te z przyczyn ekonomicznych byłyby dotknięte wykluczeniem z wszystkich przejawów życia osobistego i społecznego (Jackowski, Zalasiński 2013: 22). Jest to także konstytucyjne prawo obywatela, który oczekuje od organów państwa określonych świadczeń w sytuacji dotknięcia go niekorzystnymi zdarzeniami. Ustrojodawca stwierdził dalej, że formy zabezpieczenia społecznego określone zostaną ustawowo (Jackowski, Zalasiński 2013: 22), do ustawodawcy zatem należy wybór, w jaki sposób dokona on regulacji prawnych istnienia zabezpieczenia społecznego. $Z$ drugiej strony na ustawodawcę nałożony został na niego obowiązek uregulowania kwestii przedmiotowej. Swoboda wyboru regulacji zabezpieczeniowych nie jest jednak nieograniczona - nie można doprowadzać do naruszenia norm, zasad i innych wartości konstytucyjnych (Jackowski, Zalasiński 2013: 23).

W szczegółowo pojętej problematyce zabezpieczenia społecznego można wyróżnić ubezpieczenia społeczne, które należy traktować jako technikę zabezpieczenia społecznego. Ustawodawca, odwołując się do istoty ubezpieczeń społecznych, uregulował ich zakres w ustawie z dnia 13 października 1998 r. o systemie ubezpieczeń społecznych (Dz. U. z 2016 r., poz. 963).

Świadczenia z ubezpieczenia społecznego, które otrzymuje osoba w razie wystąpienia wobec niej sytuacji niekorzystnej, pochodzą z określonych środków. Źródłem finansowym świadczeń ubezpieczeniowych są składki. Obowiązek ich uiszczania powstaje z chwilą powstania tytułu do ubezpieczenia społecznego. Obowiązek zgłoszenia do ubezpieczenia ma wymiar wynikający z ustawy, czyli nałożony przez przepisy prawa. $\mathrm{O}$ istnieniu obowiązku składkowego przesądza tytuł do ubezpieczenia.

Konstytucja w art. 84 pozwala na nakładanie na obywateli ciężarów i świadczeń publicznych, których ponoszenie jest obowiązkiem obywatelskim. Przez te środki realizowany jest konstytucyjny mechanizm zabezpieczenia społecznego, a w tym przede wszystkim - ubezpieczeń społecznych. Ubezpieczeni, którzy opłacają składki, 
korzystają z gwarancji ubezpieczeniowej z chwilą ziszczenia się określonego ryzyka. Uzyskanie ochrony w postaci gwarancji ubezpieczeniowej nie jest darmowe. Wobec podmiotów korzystających z takiej ochrony ma zastosowanie instytucja ekspektatywy, czyli oczekiwania prawnego (będącego sytuacją prawną prowadzącą do powstania prawa podmiotowego - Jackowski, Zalasiński 2013: 23). W tym zakresie istnieje tutaj zasada wzajemności - z jednej strony opłacenie składki ubezpieczeniowej na ubezpieczenie, a z drugiej obowiązek wypłaty świadczenia w przyszłości w zamian za składki, pod warunkiem spełnienia również innych ustawowych przesłanek.

Ubezpieczeni nie mogą kształtować samodzielnie wysokości wnoszonej składki ubezpieczeniowej (jej wysokość każdorazowo określona jest przepisami ustawowymi). Mogą oni co najwyżej wpływać na jej wysokość poprzez wielkość wynagrodzenia, jakie osiągają, co odzwierciedla się w wysokości przeciętnego wynagrodzenia w danym roku.

Obecnie obowiązująca konstrukcja składki na ubezpieczenie społeczne została reaktywowana wraz z reformą całego systemu ubezpieczeń społecznych, która miała miejsce w 1999 r. na mocy ustawy o systemie ubezpieczeń społecznych (Dz. U. z 2016 r., poz. 963). Powróciła ona do tradycyjnej koncepcji składki na poszczególne rodzaje ubezpieczeń społecznych. Świadczenia z ubezpieczeń społecznych zaczęły opierać się na fakcie wpłaconych składek. Powstał w związku z tym istotny dla ubezpieczenia społecznego mechanizm korelacji składki oraz świadczeń ubezpieczeniowych (Pacud 2011), składka na ubezpieczenie stała się zatem nieodzownym elementem istniejącego systemu ubezpieczeń społecznych.

Ubezpieczenia społeczne należy odróżnić od zaopatrzenia społecznego. Kryterium odróżnienia stanowi brak składki w zaopatrzeniu społecznym. Brak istnienia składkowości to cecha podstawowa zaopatrzenia społecznego (Wantoch-Rekowski 2014: 53). Podmiotem finansującym jest Skarb Państwa. Osoby zainteresowane pośrednio bądź bezpośrednio nie partycypują w kosztach tego systemu (Modliński 1968: 86). Nabycie prawa do świadczenia wynika z woli ustawodawcy (Wantoch-Rekowski 2014: 53). Zaopatrzenie społeczne dotyczy niewielkiej grupy społecznej skupionej w szczególnego rodzaju grupach zawodowych (m.in. sędziowie, funkcjonariusze policji, żołnierze zawodowi), stąd można stwierdzić, że system zaopatrzenia społecznego nie jest tak bardzo rozbudowany, jak ubezpieczenia społeczne (Wantoch-Rekowski 2014: 53).

Celem niniejszego opracowania jest próba zdefiniowania składek na ubezpieczenie społeczne poprzez pryzmat obowiązującego ustawodawstwa (metodologia normatywistyczna), wskazanie ich cech w odniesieniu do ukształtowanych poglądów w doktrynie, a także w oparciu o aktualne orzecznictwo sądowe. 


\section{Funkcje składek na ubezpieczenie społeczne}

Funkcjonowanie składek na ubezpieczenie społeczne w obrocie poprzedzone jest wieloma czynnościami, które sankcjonują powstanie obowiązku ich zapłaty, a z drugiej strony zakresu ochrony ubezpieczeniowej, jakie dają ubezpieczenia społeczne w zamian za wniesioną składkę. Za składkę ubezpieczeniową osoba otrzymuje asekurację przed stratami wynikającymi z działania ryzyk losowych (Pacud 2011).

Składka może być łączna albo ustalona dla każdego rodzaju z ryzyk. Zróżnicowanie składki według podziału na ryzyka doprowadza do wyodrębnienia składki na ryzyko chorobowe, ryzyko emerytalne, ryzyko śmierci żywiciela oraz ryzyko wypadku przy pracy (Jędrasik-Jankowska 2014: 46).

W ubezpieczeniach społecznych występowanie ryzyka sprowadza się głównie do ryzyka fizjologicznego oraz pozostawania bez zarobku z powodu braku pracy (Modliński 1968: 93). Oznacza to, że państwo po dokonaniu zapłacenia składki przejęło na siebie ochronę przed ryzykiem na wypadek niezdolności do pracy czy też choroby, starości lub bezrobocia. Jednostka nie pozostaje sama sobie w razie wystąpienia niekorzystnych dla niej zjawisk (Jackowiak 1964: 103). Oczywiście, ochrona ubezpieczeniowa, którą otrzymuje sią za opłaconą składkę, sprowadza się tylko do gwarancji wypłaty świadczeń ubezpieczeniowych, dodatkowo jednak należy spełnić odpowiednie warunki do nabycia prawa do świadczenia. Brak istnienia prawa nie spowoduje tego, że państwo przejmie na siebie rolę w jego wypłacie. Świadczenie z ubezpieczenia społecznego istnieje w razie zajścia określonego wypadku (zdarzenia losowego) i jest tylko wyrównaniem ubezpieczonemu uszczerbku (w postaci całkowitej lub częściowej szkody) poniesionej wskutek wypadku. Może być też związane z dostarczeniem środków na wydatki zwiększone na skutek tego zdarzenia (Modliński 1968: 94).

Składki w sensie prawnym są świadczeniem wzajemnym. Płacone mogą być tylko przez pracodawcę, tylko przez pracownika albo wspólnie. Odpłatność może być w częściach równych bądź nierównych (Jędrasik-Jankowska 2014: 45). Składki stanowią wkład pracownika w celowy fundusz, ponieważ są umniejszoną częścią funduszu płac (Zieliński 1994: 173). Zgodnie z zasadą wzajemności za wniesioną składkę powinno nabyć się prawo do świadczenia, nie można jednak go nabyć, gdy z mocy ustawy nie podlega się obowiązkowym albo dobrowolnym ubezpieczeniom społecznym. Gdyby jednak również i ryzyko nie ziściło się (pomimo opłaconej składki), to brak jest prawnych możliwości żądania zwrotu wniesionych składek.

W razie spełnienia warunków ustawowych ubezpieczony ma prawo do świadczenia niezależnie od wysokości środków zgromadzonych na funduszu (Piotrowski 1973: 191). Istnieje jednak ścisły związek pomiędzy świadczeniem a składką w takim ujęciu, że prawo do świadczenia uzależnione jest od faktu opłacenia składki na ubezpieczenie społeczne, a wysokość świadczenia zależy w znacznym stopniu od wysokości 
składki na ubezpieczenie społeczne. Brak powiązania obu elementów może świadczyć o zatraceniu cech ubezpieczenia społecznego (Modliński 1968: 94).

W ubezpieczeniach społecznych dostosowanie składki do prawdopodobieństwa wystąpienia zdarzenia i rozmiarów szkody odbywa się w odniesieniu do całych zbiorowości, nie jest naruszone przy tym zasadnicze nastawienie na zaspokojenie indywidualnych potrzeb. Składka określana jest w stawkach procentowych od otrzymanego wynagrodzenia. Przyjmuje się też stosowanie wysokości składki w formie ryczałtu, który nie odpowiada faktycznym kosztom ubezpieczenia poszczególnych osób do tych grup należących czy też do całych grup (Modliński 1968: 108). Z punktu widzenia indywidualnego aspektu ubezpieczenia składka uzależniona jest od indywidualnego wynagrodzenia każdego ubezpieczonego. Ta indywidualizacja składki, czyli jej rozpisanie pomiędzy pracowników, wyrażona jest m.in. w ustaleniu składki na ubezpieczenie społeczne w określonej proporcji do wynagrodzenia ubezpieczonego (Jędrasik-Jankowska 2014: 43).

Składki usytuowane zostały w specjalnie utworzonym, wyodrębnionym funduszu działającym na rzecz osób, które biorą udział w społecznym procesie pracy. Jest on finansowany $z$ dochodu narodowego wytworzonego przez te osoby, czyli przez płace (Jędrasik-Jankowska 2014: 43). Tworzony na potrzeby gromadzenia składek Fundusz Ubezpieczenia Społecznego istniał już przed reformą ubezpieczeń społecznych. Powołany został na mocy ustawy z dnia 25 listopada 1986 r. o organizacji i finansowaniu ubezpieczeń społecznych (Dz. U. z 1989 r. Nr 25, poz. 137). Jego dysponentem był ZUS, a dochód stanowiły składki opłacane przez zakłady pracy. Nie posiadał on osobowości prawnej. Przejął on całość środków pochodzących ze składek i obciążony został wypłatą świadczeń na rzecz pracowników oraz członków ich rodzin. Utworzony został z określonej części produktu społecznego, co w pełni uzasadnia powstanie ubezpieczeń społecznych i związane jest z pokrywaniem kosztów jego funkcjonowania przez społeczeństwo. Element ten odróżnił składkę od podatku, a nade wszystko od idei zaopatrzenia społecznego finansowanej z podatków (danin) na rzecz państwa (Jędrasik-Jankowska 2014: 43).

W obecnym stanie prawnym Fundusz Ubezpieczeń Społecznych jest państwowym funduszem celowym. Środki tam gromadzone służą finansowaniu wypłat świadczeń z ubezpieczenia społecznego (Kitala 2013: 171). Jego przychodem są przede wszystkim płacone składki na ubezpieczenie społeczne, a jego wydatki przeznacza się na wypłatę w ramach poszczególnych świadczeń (Klimas 2013). Został on powołany do realizacji zadań z zakresu ubezpieczeń społecznych.

W związku z rodzajami wypłacanych świadczeń nastąpiło wyodrębnienie kilku rodzajów funduszy w ramach Funduszu Ubezpieczeń Społecznych: emerytalnego, rentowego, chorobowego, wypadkowego oraz rezerwowego (Wantoch-Rekowski 2014: 118-119). Fundusze te nie posiadają osobowości prawnej, a ich wyodrębnienie w ramach Funduszu Ubezpieczeń Społecznych ma charakter porządkowy i służy 
przede wszystkim powiązaniu właściwego rodzaju funduszu ze świadczeniami, które są z niego wypłacanych (Jończyk 2003: 128). Celem takiego działania ma być zapewnienie przejrzystości w realizacji gospodarki finansowej związanej ze świadczeniami dla określonych ryzyk socjalnych (Ślebzak 2013: 106). Uzasadnieniem tego zabiegu jest to, że niedobór składek wobec wydatków na świadczenia może spowodować zagrożenie finansowe dla Funduszu Ubezpieczeń Społecznych jako całości (Wantoch-Rekowski 2014: 119).

Udział danej osoby w tworzonym funduszu może być mierzony wysokością wynagrodzenia bądź uczestnictwem w systemie albo składką, swoistego rodzaju „odpisem” na ten fundusz (Jędrasik-Jankowska 2014: 43). Kwestią techniczną jest to, czy składka będzie przekazywana bezpośrednio przez przedsiębiorstwo (pracodawcę), czy też przez poszczególnych pracowników biorących udział w tworzeniu dochodu narodowego. Okoliczność ta nie dotyczy systemu pozapracowniczego, w którym składka w całości finansowana jest przez samego ubezpieczonego (Szubert 1987: 218). Przychody Funduszu Ubezpieczeń Społecznych są niezbędne do realizacji zadań z zakresu ubezpieczeń społecznych. Związane jest to z wydatkami, których głównymi elementami są wypłaty świadczeń pochodzących z tego funduszu. Przyjmuje się, że kwoty wydatków funduszu na świadczenia należą do tzw. wydatków sztywnych. Oznacza to środki finansowe pochodzące ze scentralizowanych zasobów publicznych, których wysokość jest tak określona, że wyłącza się swobodę decyzyjną organu władzy publicznej powołanego do wykonywania zadania z samodzielnej polityki wydatkowej. Na powyższe zwraca uwagę J. Wantoch-Rekowski (2014: 118-119). Fundusze, w których gromadzone są składki, nie przewidują przekazania ich osobom wskazanym przez ubezpieczonego na wypadek śmierci. Można dokonać zwrotu nadpłaconej składki. Odejściem od zasad tworzenia funduszu ubezpieczenia społecznego jest potrącenie ze składki emerytalnej opłaty za prowadzenie rachunku w otwartym funduszu emerytalnym (Jędrasik-Jankowska 2014: 43-44).

W systemie pracowniczym w okresie sprzed reformy do uiszczenia składek na ubezpieczenie społeczne zobowiązane były zakłady pracy. Składki stanowiły jak gdyby przymusowe oszczędności samych ubezpieczonych, w ten sposób pracownicy wnosili pośrednio swój wkład w tworzenie funduszu ubezpieczonych. Składki były elementem kosztów finansowych przedsiębiorstwa, wpływały bezpośrednio na ceny nabywanych towarów i usług (Wantoch-Rekowski 2014: 97).

Rozłożenie ciężaru składki pomiędzy pracowników i pracodawców jest, jak zauważa W. Szubert, sprawą bardziej złożoną, aniżeli mogłoby się to wydawać. Opłacenie składki nie musi być równoznaczne z rzeczywistym ponoszeniem jej ciężaru, ponieważ może on być przerzucany na inne podmioty. Przykładem jest tu składka pracodawcy na pracownika w postaci obniżki płacy czy też przeniesienie ciężaru na konsumentów (którymi są w przeważającej mierze pracownicy), co może doprowadzić do podwyżek cen. Efekty tego przedsięwzięcia są nie do końca jasne do przewidzenia, zależą bowiem od koniunktury oraz od układów gospodarczych. Uzasadniony wydaje 
się być pogląd, że bez względu na to, kto opłaca składkę, stanowi ona umniejszenie bieżącego zarobku na rzecz funduszu. Można ją nazwać swego rodzaju płacą odroczoną, której przeznaczeniem będzie zaspokojenie przyszłych potrzeb związanych z występowaniem ryzyk losowych (Szubert 1987: 218-219).

Obciążenie składką wynagrodzenia pracownika dokonane zostało poprzez podwyższenie wynagrodzenia pracownika o część składki dotychczas płaconej przez pracodawcę. Doprowadziło to do wzrostu przeciętnego wynagrodzenia za pracę. Podwyższenie wynagrodzenia o składkę to zabieg socjotechniczny. Składka formalnie wchodzi do wynagrodzenia, jednak nie stanowi przychodu pracownika, od którego odprowadzony został podatek. Związek składki z wynagrodzeniem polega na tym, że jest ono wzorcem, bazą do ustalenia indywidualnej składki. Indywidualizacja składki określa rozmiar udziału ubezpieczonego w funduszu oraz korzystanie z tego funduszu.

Składki odprowadzone do funduszu nie są prywatną własnością członka funduszu (por. wyrok Sądu Najwyższego, 2008). Ujęcie ustawowe traktuje składki na ubezpieczenie społeczne jako stopę procentową do podstawy wymiaru (przychodu, wynagrodzenia), oddzielnie według każdego rodzaju ubezpieczenia. Przyjęte w ten sposób rozwiązania doprowadziły do koncepcji podziału składki emerytalnej i rentowej pomiędzy pracodawcę i pracownika, określonych jako płatnika i ubezpieczonego (Jończyk 2003: 23). Dopuszcza się również możliwość finansowania składek przez inne podmioty (finansowanie składek przez państwo). Finansowanie składki ma swoje istotne konsekwencje przy ustalaniu świadczeń i ich wysokości. Doprowadziło to do metody świadczeń bezpośrednio zależnych od sumy wniesionych składek, czyli do systemu zdefiniowanej składki. Składka stanowi miarę ochrony i w związku z tym nie powinna być zmniejszana przez występowanie opłat. Wysokość składek na poszczególne ubezpieczenia wyrażona jest $w$ formie stopy procentowej. Stopy składek emerytalnych, rentowych i chorobowych są jednakowe dla wszystkich ubezpieczonych, bez względu na to, czy podlegają ubezpieczeniu obowiązkowemu, czy dobrowolnemu (zasada równości). Zróżnicowaniu podlega jedynie stopa procentowa składki na ubezpieczenie wypadkowe w odniesieniu do poszczególnych płatników składek w zależności od zagrożeń zawodowych i ich skutków (Jędrasik- Jankowska 2014: 43-44).

Wysokość składki wpływa na korekty w zakresie podziału dochodu narodowego. Najsilniej wpływ ten zaznacza się tam, gdzie wymierzana jest na zasadach jednolitych w stosunku do wszystkich pracowników - wówczas najsilniej zaznaczają się dysproporcje pomiędzy obciążeniem składkowym różnych kategorii pracowników a korzyściami, jakie odnoszą oni z tytułu pobierania świadczeń (Jędrasik-Jankowska 2014: 43-44).

Wynikająca stąd redystrybucja dochodu występuje w różnych przekrojach. Redystrybucja o charakterze pionowym występuje w przypadku pracowników o różnej wysokości zarobków. Ci z niższymi zarobkami z natury rzeczy przyczyniają się do gromadzenia funduszów ubezpieczeniowych w mniejszym stopniu, natomiast w większym 
stopniu mogą oni z racji własnych warunków życiowych, które bardziej eksponują ich na ryzyka losowe, korzystać ze świadczeń ubezpieczeniowych (Szubert 1987: 219). Redystrybucja może następować w odniesieniu do pracowników reprezentujących zbliżoną skalę zarobków, ale narażonych z różnych przyczyn na ryzyko chorób, przedwczesnej niezdolności do pracy czy wypadku przy pracy. Czynnikiem redystrybucji może być też wiek czy płeć ubezpieczonego, a także przynależność do określonej grupy zawodowej albo zatrudnienie w zakładach stwarzających różne zagrożenie dla życia i zdrowia pracownika. Innym rodzajem dyferencjacji składki może być różnicowanie wymiaru składki w przekroju międzyzakładowym odpowiednio do stopnia niebezpieczeństw, jakie stwarza ich działalność nie ze względu na charakter branży, ale z uwagi na warunki, jakie proponuje pracodawca, a które wypływają na polepszenie bądź pogorszenie stanu bezpieczeństwa pracownika. Ten rodzaj dyferencjacji stosowany jest głównie dla celów prewencyjnych w ubezpieczeniu wypadkowym (Szubert 1987: 219).

W oparciu o przeprowadzone rozważania można wyprowadzić wniosek, że składka na ubezpieczenie społeczne jest świadczeniem pieniężnym przekazywanym przez płatnika składek bądź ubezpieczonego na konto tworzonego funduszu w celu zapewnienia ochrony przed skutkami poniesionego ryzyka w przypadku ziszczenia się zdarzenia losowego, ich funkcjonowanie jest zatem naturalnym elementem prawidłowego działania ubezpieczeń społecznych.

\section{Pojęcie i cechy składki na ubezpieczenie społeczne}

W obecnie obowiązujących regulacjach prawnych dotyczących ubezpieczeń społecznych nie ma legalnej definicji składki na ubezpieczenie społeczne. Jej pojęcie jest raczej wytworem historycznego rozwoju stosunków społecznych oraz celu, któremu ma ona służyć (Jędrasik-Jankowska 2014: 43).

Terminu "składka"można poszukiwać w przepisach prawa cywilnego. W umowie ubezpieczenia składka jest zobowiązaniem wzajemnym za udzielenie gwarancji ubezpieczeniowej, czyli spełnienia określonego świadczenia w przypadku, gdyby ziścił się określony wypadek (Jończyk 2007: 3-4). W podobnym kontekście należy traktować składkę na ubezpieczenia społeczne - jako świadczenie obowiązkowe, które daje prawo do dochodzenia roszczenia określonych świadczeń pieniężnych w przypadku wystąpienia określonych wypadków przewidzianych w ustawie (Jończyk 2007: 4).

Powodem istnienia składki ubezpieczeniowej stała się konieczność przeznaczania części całkowitego produktu społecznego na tworzenie funduszu mającego zabezpieczać osoby biorące udział w tworzeniu takiego funduszu w przypadku, gdy ten udział stanie się w przyszłości dla nich niemożliwy (Jędrasik-Jankowska 2014: 43).

Ustawodawca nie przewidział definicji składki w ustawie z dnia 13 października 1998 r. o systemie ubezpieczeń społecznych (Dz. U. z 2016 r., poz. 963), jednak nie bez 
przyczyny składkom poświęcony został rozdział 3 tej ustawy (Zasady ustalenia składek na ubezpieczenia społeczne). Został on poprzedzony przepisami dotyczącymi zasad podlegania ubezpieczeniom społecznym, stąd wniosek, że ustawodawca, umiejscawiając składki dopiero w rozdziale 3 ustawy, daje wyraz temu, że ich funkcjonowanie jest konsekwencją istnienia ubezpieczenia obowiązkowego bądź zgłoszenia do ubezpieczenia dobrowolnego. Czynnością poprzedzającą powstanie obowiązku zapłaty jest objęcie ubezpieczeniem. Z zapisów ustawy można również wysnuć wniosek, że nie mamy do czynienia z jedną składką ubezpieczeniową. Jest nich kilka, a każda z nich związana jest z konkretnym ubezpieczeniem (art. 4 pkt 3 ustawy o systemie ubezpieczeń społecznych, który pośrednio odsyła do art. 1 tejże ustawy).

O składce ubezpieczeniowej można mówić wtedy, gdy jest to składka na ubezpieczenie społeczne osoby fizycznej podlegającej chociaż jednemu z ubezpieczeń społecznych (emerytalne, rentowe, chorobowe i wypadkowe). Inne podmioty (osoby prawne, nie posiadające osobowości prawnej) nie są uprawnione do tego, aby polegać ubezpieczeniom społecznym, nie są więc one ubezpieczonymi w rozumieniu ustawy o systemie ubezpieczeń społecznych (art. 4 pkt 1) oraz nie są one stronami stosunku ubezpieczeniowego. Podobnie przedstawia się tu sprawa osoby prawnej będącej płatnikiem składki. W tym znaczeniu pomimo obowiązku opłacania składki na ubezpieczenie społeczne osoba taka nie nabędzie nigdy prawa do świadczenia, pomimo że taką składkę opłaca. Jest kwestią wtórną, czy składka będzie przekazywana przez przedsiębiorstwo, czy też przez poszczególnych pracowników, do opłacenia której zostali zobowiązani (Jędrasik-Jankowska 2014: 43).

Składkę na ubezpieczenie społeczne najlepiej zdefiniować podając jej cechy. Jej klasyczne atrybuty zostały nakreślone przed doktrynę. W. Szubert określił składkę jako świadczenie charakteryzujące się:

a) przymusowością, która wynika z przymusowego charakteru ubezpieczenia społecznego,

b) celowością, tzn. przeznaczeniem składek na pokrycie ciężaru świadczeń łagodzących skutki zaistniałych zdarzeń losowych,

c) odpłatnością, tzn. powiązaniem ze świadczeniem wzajemnym instytucji ubezpieczeniowej w razie zajścia zdarzeń (Szubert 1987: 217).

Przymusowość oznacza, że należności z tytułu składek na ubezpieczenie społeczne mogą być egzekwowane nie na drodze sądowej czy też arbitrażowej (jak to jest w ubezpieczeniach gospodarczych), ale w trybie właściwym dla ściągania podatków czy opłat publicznych. Przymusowość stanowi konsekwencję obowiązkowego charakteru ubezpieczenia społecznego. Decyzji o przystąpieniu do ubezpieczenia nie pozostawia się jednostce, ale powierza się ją kompetencji państwa. Zmusza się w ten sposób jednostkę do dbałości o zabezpieczenie sobie i członkom rodziny bytu na wypadek ziszczenia się określonego zdarzenia losowego. Może to stanowić udział dla osób lepiej zarabiających poprzez uczestnictwo w ubezpieczeniu prywatnym. Objęcie ubezpieczeniem społecznym następuje z mocy samego prawa, a więc automatycznie. 
Ten element ma na celu zapewnienie uzyskania założonego zakresu podmiotowego oraz pozyskanie środków przeznaczonych na finansowanie świadczeń ubezpieczeniowych (Zieleniecki 2011: 272). Łagodzeniem przymusowości składkowej przychodzi z pomocą wiele instrumentów przeznaczonych ze strony państwa dla podmiotów ubezpieczeń społecznych (ulgi w opłacaniu składek, restrukturyzacja, abolicja).

Celowość zakłada takie gospodarowanie funduszami pochodzącymi ze składek na ubezpieczenia społeczne, aby były one obracane wyłącznie na cele z nimi powiązanymi. Zakłada również konieczność takiego gospodarowania funduszem, aby jego środki były wydatkowane zgodnie z jego przeznaczeniem, tzn. wyłącznie na pokrycie kosztów świadczeń łagodzących skutki zdarzeń losowych objętych ryzykiem ubezpieczeniowym (Zieleniecki 2011: 272).

Odpłatność składek związana jest z obowiązkiem zapłaty. Nie musi ona oznaczać wcale równowartości składek i świadczeń w rozrachunku indywidualnym, ponieważ o powstaniu uprawnienia do świadczeń decyduje czynnik losowości (Szubert 1987: 217). Może się tak zdarzyć, że pracownik płacący składkę rentową w okresie swojego zatrudnienia nie skorzysta ze świadczeń rentowych. Czynnik losowości może kształtować się niejednakowo w stosunku do różnych ubezpieczonych, w związku z tym przyjmuje się założenie, że nie wszyscy ubezpieczeni skorzystają z ochrony ubezpieczeniowej. Odpłatność zakłada związek pomiędzy obowiązkiem zapłacenia składki a prawem do świadczenia. Materializuje się on w przypadku ziszczenia się przewidzianych prawem zdarzeń. Składka stanowi gwarancję, że w razie wystąpienia zdarzenia losowego ubezpieczony otrzyma określone świadczenie od instytucji ubezpieczeniowej, która je pobrała (Zieleniecki 2011: 272). Tam, gdzie pobieranie składki nie gwarantuje celowego przeznaczenia gromadzonych na tej drodze środków oraz gdzie nie wiąże się ono z powstaniem uprawnień do świadczeń wzajemnych, składka zatraca swój charakter jako instytucja prawa ubezpieczeniowego i upodabnia się do podatku (Szubert 1987: 217). W tym przypadku wymiar świadczeń ma niewiele wspólnego z opłacaną składką, staje się wyrazem oceny potrzeb, zazwyczaj skromnie pojmowanych, ale z tendencją do ich uchwycenia na szerszej płaszczyźnie niż byłoby to możliwe, ale z przy bezwzględnym przestrzeganiu ściśle ubezpieczeniowych rygorów (Szubert 1973: 237). Odróżnienie pojęcia składki i podatku nie pozwala na przyjęcie jednej instytucji prawnej dla obu tych danin, ponieważ w przeciwnym razie takie działanie byłby nieracjonalne (Wantoch-Rekowski 2005: 97). W ubezpieczeniach społecznych składkę ustalono na takim samym poziomie, aby zapewnić osiągnięcie równowagi pomiędzy dochodami i wydatkami funduszu ubezpieczeniowego w rachunku globalnym. Opłacenie wyższej składki może prowadzić do uzyskania wyższego świadczenia, zatem wysokość składki i długość okresu jej opłacenia wpływa na rozmiar świadczenia ubezpieczeniowego. Nie można jednak mówić o ekwiwalentności świadczeń, ponieważ składka stanowi miarę ogólnego wkładu na tworzone fundusze, świadczenie zaś ubezpieczonego nie jest ścisłym odpowiednikiem własnego wkładu ubezpieczeniowego (Zieliński 1994: 190). Ekwiwalentność składki i ubezpieczenia 
jest modyfikowana przez zasady solidarności społecznej - elementy tzw. społecznego wyrównania.

Inetta Jędrasik-Jankowska stwierdza, że składka na ubezpieczenie społeczne jest świadczeniem o charakterze przymusowym, celowym, odpłatnym i bezzwrotnym, a więc dokonuje rozszerzenia klasycznych jej cech. Bezzwrotność pojmowana jest jako opłacenie składki w prawidłowy sposób i w prawidłowej wysokości, która nie podlega zwrotowi. Jest to cecha właściwa dla polskiego systemu ubezpieczeń społecznych. Oznacza to, że w razie niespełnienia przez ubezpieczonego warunków do nabycia prawa do świadczenia, a więc niezaistnienie zdarzenia, składka nie podlega zwrotowi. Odejściem od zasady bezzwrotności jest przekazywanie składki do otwartych funduszy emerytalnych. W przypadku śmierci członka otwartego funduszu emerytalnego dokonuje się podziału środków emerytalnych (Jędrasik-Jankowska 2014: 53).

\section{Rodzaje składek na ubezpieczenie społeczne}

\subsection{Uwagi ogólne}

Wraz z reformą ubezpieczeń społecznych doszło do wyodrębnienia kilku składek według ich rodzaju. Od tego momentu datuje się powrót do idei przedwojennej składki podzielonej (Jończyk 2003: 121). Do czasu przeprowadzenia reformy funkcjonowała jedna składka na ubezpieczenie społeczne. Była ona finansowana w całości przez pracodawcę i stanowiła $45 \%$ funduszu płac, a dla osób prowadzących działalność $60 \%$ przeciętnego wynagrodzenia w gospodarce.

Założeniem przeprowadzonej reformy ubezpieczeń społecznych była zasada samofinansowania ubezpieczeń społecznych (Ślebzak 2013: 104). Ogólnie należy przyjąć, że podział na składki ubezpieczeniowe jest konsekwencją źródeł finansowania świadczeń z ubezpieczeń społecznych, dlatego też przyjęto, że wysokość składki określona została jako procent dochodu, który stanowi jej podstawę wymiaru (Bielawska 2013: 163). To z kolei doprowadziło do wyodrębnienia samodzielnej składki bez określenia jej jako dodatkowego podatku.

Składka każdego rodzaju ubezpieczenia pełni inną rolę w ramach ubezpieczenia społecznego i opłacana jest w innej wysokości (Wantoch-Rekowski 2015: 49-50).

Oprócz składek na Fundusz Ubezpieczeń Społecznych istnieją również składki pozafunduszowe. Do nich należy składka na Fundusz Pracy oraz Fundusz Gwarantowanych Świadczeń Pracowniczych. Fundusze te obciążają pracodawców. Inny jest cel i potrzeba ich tworzenia: mają one związek z niepomyślnymi dla pracodawcy kwestiami ekonomiczno-finansowymi (np. rozwiązanie stosunku pracy z przyczyn leżących po stronie pracodawcy - Wantoch-Rekowski, 2015: 49-50). 
Składka emerytalna, rentowa oraz chorobowa opłacane są procentowo. Ich stopa procentowa jest równa dla każdej grupy ubezpieczonych. Odejściem od tej zasady jest składka wypadkowa.

Stopa procentowa składek na poszczególne fundusze przedstawia się następująco:

- 19,52\% podstawy wymiaru na ubezpieczenie emerytalne,

$-8,00 \%$ podstawy wymiaru na ubezpieczenie rentowe,

$-2,45 \%$ podstawy wymiaru na ubezpieczenie chorobowe,

- od $0,40 \%$ do $8,12 \%$ podstawy wymiaru na ubezpieczenie wypadkowe (podstawę prawną określającą procentowy wymiar składek stanowi art. 22 ust. 1 ustawy z dnia 13 października 1998 r. o systemie ubezpieczeń społecznych, Dz. U. z 2016 r., poz. 963). Zgodnie z art. 22 ust. 2 cytowanej ustawy zasady różnicowania stopy procentowej składek na ubezpieczenie wypadkowe określają przepisy o ubezpieczeniu społecznym z tytułu wypadków przy pracy i chorób zawodowych).

Podstawę wymiaru składki stanowi kwota pieniężna, jaką otrzymuje ubezpieczony. W odniesieniu do najliczniejszej grupy ubezpieczonych, jakimi są pracownicy, jest to przychód (wynagrodzenie pracownika). Sąd Najwyższy w wyroku z dnia 3 lutego 2012 r. stwierdził, że niewypłacone pracownikowi wynagrodzenie za pracę nie stanowi postawy wymiaru składek na ubezpieczenie społeczne. Podstawę wymiaru składki na ubezpieczenie emerytalne i rentowe stanowi wynagrodzenie, które jest wypłacone $w$ danym miesiącu kalendarzowym wraz z tymi składnikami i świadczeniami, które z mocy przepisów nie są wyłączone z podstawy wymiaru składek. Wynagrodzenie wypłacone ubezpieczonemu pracownikowi przez pracodawcę z opóźnieniem wykazywane jest w indywidualnym raporcie miesięcznym, składanym za ten miesiąc, w którym zostało faktycznie wypłacone i staje się wówczas podstawą wymiaru składek (wyrok Sądu Najwyższego z dnia 3 lutego 2012 r.).

W przypadku osób prowadzących działalność pozarolniczą składka jest opłacana od wartości zadeklarowanej, jednak nie niższej niż $60 \%$ prognozowanego przeciętnego wynagrodzenia miesięcznego.

\subsection{Składlka emerytalna}

W odniesieniu do składki emerytalnej mamy do czynienia z partycypacją pracowników w finansowaniu składki na to ubezpieczenie. Obciążenie pracowników składką od wynagrodzenia wymagało wcześniejszego zabiegu ubruttowienia płacy. Polegało ono na podwyższeniu wynagrodzenia przez pracodawcę w taki sposób, by po potrąceniu składek na ubezpieczenie emerytalne, rentowe i chorobowe nie było ono niższe niż przed ubruttowieniem. Po ubruttowieniu składka wnoszona przez pracownika oraz przez pracodawcę została odniesiona do zarobku pracownika (Jędrasik-Jankowska 2014: 47). Zarówno pracownik, jak i pracodawca ponoszą w jej finansowaniu jednakowe koszty (po 9,76\% podstawy wymiaru składki). Odejściem od tej reguły są osoby prowadzące działalność gospodarczą, które samodzielnie finansują całą składkę. 
W odniesieniu do osób pobierających zasiłek dla bezrobotnych ciężar zapłaty składki przerzucony został na płatnika ze środków publicznych (Bielawska 2013: 199).

W przypadku ubezpieczonych, którzy przystąpili do otwartego funduszu emerytalnego, część ich składki emerytalnej przekazywana jest przez ZUS do tego funduszu (2,92\% podstawy wymiaru składki jest odprowadzana przez zakład do wybranego przez ubezpieczonego otwartego funduszu emerytalnego, a 4,38\% podstawy wymiaru składki jest ewidencjonowane przez zakład na subkoncie, o którym mowa w art. 40 a). W przypadku nieodprowadzania lub zaprzestania odprowadzania składki do otwartego funduszu emerytalnego, o którym mowa w ust. 3d, część składki na ubezpieczenie emerytalne wynosząca 7,3\% podstawy wymiaru składki jest ewidencjonowana przez zakład na subkoncie, o którym mowa w art. 40a (o czym stanowi art. 22 ust. 3 ustawy z dnia 13 października 1998 r. o systemie ubezpieczeń społecznych, Dz. U. z 2016 r., poz. 963). W przypadku, gdy ubezpieczony nie jest członkiem otwartego funduszu emerytalnego, wówczas $12,22 \%$ jego składki trafia na konto ZUS, natomiast 7,3\% na subkonto.

Fundusz emerytalny zarządzany jest przez podmioty prywatne - powszechne towarzystwa emerytalne. Składki mogą być inwestowane w określone kategorie instrumentów finansowych (Bielawska 2013: 199). Uczestnictwo w I filarze (ubezpieczenie w ZUS) oraz w II filarze według twórców reformy miało zapewnić przyszłym emerytom dochód służący zaspokojeniu podstawowych potrzeb (Bielawska 2013: 308). Podtrzymanie przez przyszłego emeryta dotychczasowego standardu życia powoduje konieczność ponoszenia kosztów w postaci opłacania składek na dodatkowe ubezpieczenia (III filar - ubezpieczenie komercyjne). Funkcjonowanie podziału składki emerytalnej na dwa filary ubezpieczenia miało zapewnić emerytom dwa źródła ich utrzymania - emeryturę repartycyjną (I filar) oraz emeryturę kapitałową (II filar). Kolejne reformy zacierają dotychczasowy obraz podziału i funkcjonowania składki emerytalnej w ramach dwóch filarów, łamiąc tym samym dotychczasowe koncepcje i założenia, jakie miała spełniać funkcjonująca składka emerytalna w obrębie tych filarów. Przed kolejną reformą dotyczącą składki emerytalnej, dokonaną w 2014 r. na mocy ustawy z dnia 6 grudnia 2013 r. o zmianie niektórych ustaw w związku z określeniem zasad wypłaty emerytur ze środków zgromadzonych w otwartych funduszach emerytalnych (Dz. U. z 2013 r., poz. 1717), podział składki emerytalnej na dwa filary oraz uczestnictwo w otwartym funduszu emerytalnym był obowiązkowy dla osób urodzonych po 31 grudnia 1968 r. Obecnie składka kapitałowa (II filar oraz subkonto) odprowadzana jest już tylko z części całej składki emerytalnej, jaką opłaca ubezpieczony.

Obowiązek odprowadzania części składki emerytalnej do wybranego otwartego funduszu emerytalnego nie jest niezgodny z art. 67 ust. Konstytucji RP. Stworzony w ten sposób przez ustawodawcę system emerytalny nie został skonstruowany dla indywidualnego ubezpieczonego, lecz dla ogółu objętych ubezpieczeniem emerytalnym, którzy w przyszłości staną się beneficjentami systemu emerytalnego (wyrok Sądu Najwyższego z dnia 4 czerwca 2008 r., II UK 12/08 - zob. Wajda, 2011: 411 i n.). 
Wzrost liczby emerytów i spadek liczby ubezpieczonych powoduje konieczność kolejnych reform emerytalnych, m.in. wydłużenie wieku emerytalnego czy też transfer części składek zgromadzonych w otwartym funduszu emerytalnym na konto w ZUS. Wydłużenie wieku emerytalnego osób ubezpieczonych przyczynia się do tego, że będą oni zmuszeni płacić składki przez dłuższy okres ubezpieczenia.

Lata 2010-2014 to okres stopniowego odwracania reformy wprowadzonej w 1999 r. Towarzyszyła jej troska o krótkotrwały stan finansów publicznych, pozostający pod wpływem rozwijającego się kryzysu światowego. Nowością była redukcja składki przekazywanej do otwartego funduszu emerytalnego oraz wprowadzenie subkonta w ZUS, a także wprowadzenie dobrowolności w opłacaniu składki (w domyślnym znaczeniu przyjęcie mechanizmu opłacania składek tylko w ZUS). Wprowadzono również suwak bezpieczeństwa, polegający na stopniowym wycofywaniu środków z otwartego funduszu emerytalnego do ZUS przez 10 lat przed osiągnięciem wieku emerytalnego. Jednocześnie zrezygnowano z funkcjonowania emerytur kapitałowych. Dokonano także umorzenia obligacji skarbowych w portfelach OFE $i$ jednocześnie zakazano funduszom inwestowania w obligacje skarbowe. Zniesiono również finalną stopę zwrotu (Sektor funduszy emerytalnych, 2016: 5).

Głównym argumentem wysuwanym przeciw istnieniu OFE był poziom refundowanych składek do FUS (pokrycie różnicy między nową a starą składką do FUS), co związane jest poniekąd z dualistycznym funkcjonowaniem świadczeń, z jednej strony bazującym na zdefiniowanym świadczeniu, a z drugiej na zdefiniowanej składce. Pierwotnie miało to być w dużym stopniu zabezpieczone przychodami z prywatyzacji, ale praktyka okazała się inna. W rzeczywistości dotacja ta nie ma charakteru kosztu, a raczej inwestycji, bowiem oszczędności w OFE zmniejszają przyszłe wydatki FUS. W kryzysowej rzeczywistości dominowała tylko perspektywa krótkoterminowa (Sektor funduszy emerytalnych, 2016: 4) .

W okresie od 1 kwietnia do 31 lipca 2014 r. członkowie otwartych funduszy emerytalnych podejmowali decyzję, czy składka w wysokości 2,92\% podstawy wymiaru nadal ma być przekazywana do OFE, czy też ma zostać zewidencjonowana na subkoncie w ZUS wraz z przekazywaną już na to subkonto składką w wysokości 4,38\% podstawy wymiaru składki. Decyzja o sposobie przekazywania składek (do OFE czy na subkonto), którą podjął członek OFE, nie była ostateczna - można ją było zmienić w okresie od kwietnia do lipca 2014 r., a następnie co 4 lata (tzw. okienka transferowe). Oznacza to wprowadzenie dobrowolności w zakresie przekazywania przyszłych składek do OFE (Składka na ubezpieczenie emerytalne).

Podstawa wymiaru składki na ubezpieczenie emerytalne została ograniczona do trzydziestokrotności prognozowanego przeciętnego wynagrodzenia w gospodarce (art. 19 ustawy z dnia 13 października 1998 r. o systemie ubezpieczeń społecznych, Dz. U. z 2016 r., poz. 963). Przekroczenie tej sumy powoduje zaprzestanie dalszego pobierania składki emerytalnej. W roku 2017 kwota rocznego ograniczenia podstawy 
wymiaru składki na ubezpieczenie emerytalne i rentowe wynosi 127.890zł (Monitor Polski z 2016 r. poz. 1188).

Składki wpłacone do ZUS podlegają corocznej waloryzacji, tj. pomnożeniu przez wskaźnik waloryzacji. Środki przekazywane do OFE pomnażane są poprzez inwestycje na rynkach finansowych. Waloryzacja środków zewidencjonowanych na kontach emerytalnych w ZUS zależy od inflacji i wzrostu płac w gospodarce. Składki ewidencjonowane na subkonto podlegają waloryzacji wskaźnikiem równym średniorocznej dynamice wartości PKB za okres ostatnich pięciu lat (Składka na ubezpieczenie emerytalne). Waloryzacja w tym ujęciu oznaczać będzie konieczność urealnienia składek zapisywanych na indywidualnych kontach, ponieważ w perspektywie dalszych lat ich realna wartość nie będzie odpowiadała rzeczywistości (Jędrasik-Jankowska 2001: 166).

Wskaźnik waloryzacji uzależniony jest od wzrostu cen towarów i usług konsumpcyjnych powiększonego ogółem o wzrost realny przypisu składek na ubezpieczenie emerytalne w roku kalendarzowym poprzedzającym termin waloryzacji w stosunku do roku poprzedniego (Uziak 2009: 299-300). O nowej wysokości składki decyduje wysokość wskaźnika waloryzacji, który w danym roku kalendarzowym podawany jest za rok poprzedni (wskaźnik waloryzacji składek za rok 2015 wynosi 105,37\%, Monitor Polski z 2016 r. poz. 456). Waloryzacja składek przeprowadzana jest corocznie począwszy od 1 czerwca 2000 roku. Podlegają jej składki zewidencjonowane na koncie ubezpieczonego na dzień 31 stycznia roku, za który przeprowadzana jest waloryzacja (Wantoch-Rekowski 2014: 245). Od waloryzacji corocznej należy odróżnić waloryzację składek przeprowadzanych kwartalnie. Metodę tę stosuje się do osób, którym ustalono prawo do emerytury. Przy ustalaniu wysokości emerytury kwota składek zewidencjonowanych na koncie po dniu 13 stycznia w roku, za który przeprowadzono ostatnią waloryzację, waloryzowana jest kwartalnie (art. 25 a ustawy z dnia 17 grudnia 1998 r. o emeryturach i rentach z Funduszu Ubezpieczeń Społecznych, Dz. U. z 2016 r., poz. 887).

\subsection{Składka rentowa}

Drugą po składce emerytalnej, stanowiącą o finansowym istnieniu Funduszu Ubezpieczeń Społecznych, jest składka rentowa. Jest ona osadzona w tworzonym w ramach Funduszu Ubezpieczeń Społecznych funduszu rentowym.

Skutkiem wynikającym z podlegania ubezpieczeniu rentowemu jest konieczność opłacania składki na to ubezpieczenie. Obowiązkiem ubezpieczenia z tytułu ubezpieczenia rentowego objęte zostały osoby, które wykonują szeroko rozumianą pracę (tj. działalność zapewniającą środki utrzymania) albo też takie, którym z różnego tytułu wypłaca się wybrane świadczenia pieniężne (Cichosz 2013: 245).

Łączna wysokość składki na ubezpieczenie rentowe wyrażona jest w procentowej stawce, która jest równa dla wszystkich ubezpieczonych (Cichosz 2013: 249). Wynosi ona $8 \%$ podstawy wymiaru. Udział płatnika w finansowaniu składki wynosi $6,5 \%$ podstawy jej wymiaru, natomiast ubezpieczonego $-1,5 \%$ podstawy jej wymiaru. 
Podstawą wymiaru składki stanowi jest głównie przychód (pracowników oraz osób wykonujących pracę nakładczą).W przypadku osób prowadzących działalność gospodarczą stanowi ją zadeklarowana kwota nie niższa niż $60 \%$ prognozowanego średniego wynagrodzenia miesięcznego przyjętego do ustalenia kwoty ograniczenia rocznej podstawy wymiaru składek. Dla osób kontynuujących ubezpieczenia bądź też ubezpieczonych dobrowolnie jej podstawę stanowi zadeklarowana kwota, nie niższa niż minimalne wynagrodzenie (Cichosz 2013: 249). Druga grupa podmiotów opłaca składkę samodzielnie.

W przypadku ziszczenia się określonych ryzyk z ubezpieczenia rentowego (tj. niezdolność do pracy, śmierć, śmierć żywiciela) wypłacane są renty z tytułu niezdolności do pracy, renty szkoleniowe, renty rodzinne i zasiłek pogrzebowy. Warunki nabywania prawa do tych świadczeń zostały określone w ustawie z dnia 17 grudnia 1998 r. o emeryturach i rentach z Funduszu Ubezpieczeń Społecznych (Dz. U z 2016 r., poz. 887). Tak samo, jak to jest w przypadku składki emerytalnej, roczna podstawa wymiaru składki na ubezpieczenie rentowe osób ubezpieczonych w danym roku kalendarzowym nie może być wyższa od kwoty odpowiadającej trzydziestokrotności prognozowanego przeciętnego wynagrodzenia miesięcznego w gospodarce narodowej na dany rok kalendarzowy.

Od nadwyżki ponad te kwoty nie opłaca się składek na ubezpieczenie rentowe.

\subsection{Składka chorobowa}

Kolejną składką wchodzącą do Funduszu Ubezpieczeń Społecznych jest składka chorobowa. Jest ona elementem tworzonego w ramach Funduszu Ubezpieczeń Społecznych podfunduszu chorobowego. Składka na ubezpieczenie chorobowe wynosi 2,45\% podstawy jej wymiaru. Składki chorobowe finansowane są w całości przez samych ubezpieczonych (art. 16 ust. 2, ust. 4, ust. 5a, ust. 11 ustawy z dnia 13 października 1998 r. o systemie ubezpieczeń społecznych, Dz. U. z 2016 r., poz. 963), zatem od pozostałych składek na ubezpieczenie społeczne odróżnia je podmiot finansujący: będzie nim zawsze osoba ubezpieczona. W źródle finansowania tej składki nie ma podziału jak w przypadku składki emerytalnej bądź rentowej (np. w stosunku do ubezpieczonego będącego pracownikiem, gdzie w kosztach składki partycypują zarówno pracownik, jak i pracodawca). Opłacanie składek na ubezpieczenie chorobowe może przyjąć postać obowiązkowego bądź dobrowolnego (zasady podlegania ubezpieczeniu chorobowemu określa art. 11 ustawy z dnia 13 października 1998 r. o systemie ubezpieczeń społecznych, Dz. U. z 2016 r., poz. 963).

Przez podstawę wymiaru składki na ubezpieczenie chorobowe należy rozumieć podstawę wymiaru składek na ubezpieczenie emerytalne i rentowe. Do ustalenia podstawy wymiaru składki na ubezpieczenie chorobowe nie stosuje się ograniczenia, które wynika z rocznej podstawy wymiaru składek, jak to jest w przypadku podstawy wymiaru składki na ubezpieczenie emerytalne i rentowe. W przypadku osób podlegających 
ubezpieczeniu dobrowolnemu ustawodawca wprowadza oddzielne ograniczenie podstawy wymiaru składki. Nie może ona przekraczać miesięcznie $250 \%$ prognozowanego przeciętnego wynagrodzenia (art. 19 ust. 10 ustawy z dnia 13 października 1998 r. o systemie ubezpieczeń społecznych, Dz. U. z 2016 r., poz. 963). Kwota 250\% prognozowanego przeciętnego wynagrodzenia stosowana w okresie od 1 stycznia 2016 r. do 31 grudnia 2016 r. przy ustalaniu podstawy wymiaru składki na ubezpieczenie chorobowe osób, które dobrowolnie podlegają ubezpieczeniu chorobowemu, wynosi miesięcznie 10137,50 zł (Monitor Polski z 2015 r. poz. 1306).

Ze składek pochodzących z ubezpieczenia chorobowego finansowane są takie świadczenia, jak zasiłek chorobowy, świadczenie rehabilitacyjne, zasiłek wyrównawczy, zasiłek macierzyński i zasiłek opiekuńczy (zasady ustalania prawa do tych świadczeń oraz ich wysokość uregulowana została w ustawie z dnia 25 czerwca 1999 r. o świadczeniach pieniężnych z ubezpieczenia społecznego w razie choroby i macierzyństwa, Dz. U. z 2016 r., poz. 372). Są one nazwane świadczeniami krótkoterminowymi.

W obecnym stanie prawnym w katalogu ryzyk ubezpieczeniowych, wpisanych w ramach ubezpieczenia chorobowego, wyróżniamy: czasową niezdolność do pracy z powodu choroby, odosobnienie w związku z chorobą zakaźną, zmniejszenie sprawności do pracy, konieczność opieki nad dzieckiem lub innym chorym członkiem rodziny. Skutki tego samego zdarzenia losowego mogą być różnorodne. Choroba jako zdarzenie losowe w zależności od skutków może przyjąć postać czasowej niezdolności do pracy albo trwałej niezdolności do pracy lub zmniejszenie sprawności zawodowej. Skutki o podobnym charakterze może mieć macierzyństwo (Olszewska 2013: 35), jednak w odniesieniu do ubezpieczenia chorobowego skutki takich sytuacji są czasowe, a nie trwałe.

\subsection{Składka wypadkowa}

Składka wypadkowa jest podstawowym źródłem finansowania świadczeń na to ubezpieczenie. Jej wysokość ustalana jest kwotowo bądź procentowo (tj. od wysokości wynagrodzenia ubezpieczonego, które stanowi podstawę wymiaru składki), praktyka jednak pokazuje, że dla ubezpieczeń wypadkowych stosuje się różnicowanie składki wypadkowej w zależności od poziomu istniejącego zagrożenia, jakie ma związek z wykonywaną pracą (Kitala 2013: 236).

Płatnikiem składki wypadkowej jest wyłącznie pracodawca. Ma to również swoje uzasadnienie historycznie, ponieważ z reguły był on jej płatnikiem, chociaż beneficjentem świadczeń był pracownik. Dzięki temu pracodawca jest zwolniony z odpowiedzialności cywilnej (Ślebzak 2013: 107).

Wprowadzenie ubezpieczenia wypadkowego do systemu i obciążenie składką pracodawców oznacza także konieczność wprowadzenia mechanizmów realizujących prewencyjne cele zabezpieczenia społecznego (Lach, 2010). 
Od 1999 r. ubezpieczenie wypadkowe gwarantuje prawo do świadczeń pieniężnych dla osób, które uległy wypadkowi przy pracy. Ma to istotne znaczenie szczególnie dla tych grup zawodowych, które dotychczas nie posiadały takiej formy ochrony, a z racji wykonywanego zawodu narażone były na wystąpienie ryzyko wypadku (Olszewska 2013: 36).

Zasady ustalania składek na ubezpieczenie wypadkowe, obowiązujące od 2002 r., różnicują wysokość składki na ubezpieczenie wypadkowe w zależności od warunków pracy, gałęzi gospodarki, liczby zatrudnionych pracowników oraz liczby wypadków (ustawa z dnia 30 października 2002 r. o ubezpieczeniu społecznym z tytułu wypadków przy pracy i chorób zawodowych, Dz. U. z 2015 r., poz. 1242 oraz rozporządzenie Ministra Pracy i Polityki Społecznej z dnia 29 listopada 2002 r. w sprawie różnicowania stopy procentowej składki na ubezpieczenie społeczne z tytułu wypadków przy pracy i chorób zawodowych w zależności od zagrożeń zawodowych i ich skutków, Dz. U. z 2013 r., poz. 878).

Składka na ubezpieczenie wypadkowe ustalana jest na rok składkowy, który obejmuje okres od 1 kwietnia danego roku do 31 marca następnego roku. Ustalenie tego czasookresu umożliwia uwzględnienie przy ustalaniu wysokości stopy procentowej danych pochodzących z całego poprzedniego roku kalendarzowego. Kategorie ryzyka ustalane są na podstawie danych - dostępnych w dniu 31 stycznia danego roku - Głównego Urzędu Statystycznego za trzy ostatnie lata kalendarzowe (art. 30 ust. 4 i 5 ustawy z dnia 30 października 2002 r. o ubezpieczeniu społecznym z tytułu wypadków przy pracy i chorób zawodowych, Dz. U. z 2015 r., poz. 1242, por. Lach, 2010).

Kategorię ryzyka dla płatnika składek ustala się na podstawie określonych w ustawie danych przekazywanych obowiązkowo przez płatnika składek za trzy kolejne ostatnie lata kalendarzowe do dnia 31 stycznia danego roku (art. 31 ust. 5 i 6 ustawy z dnia 30 października 2002 r. o ubezpieczeniu społecznym z tytułu wypadków przy pracy i chorób zawodowych, Dz. U. z 2015 r., poz. 1242). Wśród danych mających wpływ na ustalenie kategorii ryzyka płatnika składek ustawa w art. 30 ust. 3 wymienia ryzyko określone wskazaniami częstości poszkodowanych w wypadkach przy pracy ogółem, poszkodowanych w śmiertelnych i ciężkich wypadkach przy pracy oraz zatrudnionych w warunkach zagrożenia.

O wysokości stopy procentowej składki na ubezpieczenie wypadkowe, obowiązującej w danym roku składkowym, ZUS zawiadamia płatnika składek nie później niż do dnia 20 kwietnia danego roku (art. 32 ust. 1 ustawy z dnia 30 października 2002 r. o ubezpieczeniu społecznym z tytułu wypadków przy pracy i chorób zawodowych, Dz. U. z 2015 r., poz. 1242).

Sposób ustalania stopy procentowej składki na ubezpieczenie wypadkowe uzależniony jest od liczby ubezpieczonych zgłaszanych przez danego płatnika do ubezpieczenia wypadkowego. W zależności od liczby zgłoszonych do ubezpieczenia wypadkowego płatników dzieli się na zgłaszających do ubezpieczenia nie więcej niż 
9 ubezpieczonych oraz zgłaszających do ubezpieczenia co najmniej 10 ubezpieczonych. Dla płatników zgłaszających do ubezpieczenia wypadkowego nie więcej niż 9 ubezpieczonych ustalana jest zryczałtowana stopa procentowa składek na ubezpieczenie społeczne, natomiast dla płatników zgłaszających do ubezpieczenia wypadkowego co najmniej 10 ubezpieczonych ustalana jest zindywidualizowana stopa składki na ubezpieczenie wypadkowe. Dla składki zryczałtowanej bierze się pod uwagę stopę najwyższą z ustalanych na dany rok składkowy obejmującą wszystkie grupy działalności (stopa procentowa składki na ubezpieczenie wypadkowe płatników zgłaszających nie więcej niż 9 ubezpieczonych wynosi 50\% najwyższej stopy procentowej ustalanej na dany rok kalendarzowy dla grup działalności, zob. art. 28 ust. 1 ustawy z dnia 30 października 2002 r. o ubezpieczeniu społecznym z tytułu wypadków przy pracy i chorób zawodowych, Dz. U. z 2015 r., poz. 1242). Stopę procentową składki na ubezpieczenie wypadkowe dla płatnika składek zgłaszającego do ubezpieczenia wypadkowego co najmniej 10 ubezpieczonych ustala zakład jako iloczyn stopy procentowej składki na ubezpieczenie wypadkowe określonej dla grupy działalności. Kategorie ryzyka dla grupy działalności ustala się w zależności od określonej wskazaniami częstości: poszkodowanych w wypadkach przy pracy ogółem, poszkodowanych w śmiertelnych i ciężkich wypadkach przy pracy, stwierdzonych chorób zawodowych oraz zatrudnionych w warunkach zagrożeń, które występują w razie przekroczenia najwyższych dopuszczalnych stężeń i natężeń czynników szkodliwych dla zdrowia w środowisku pracy, do której należy płatnik składek oraz wskaźnika korygującego ustalonego dla płatnika składek (art. 28 ust. 2 ustawy z dnia 30 października 2002 r. o ubezpieczeniu społecznym z tytułu wypadków przy pracy i chorób zawodowych, Dz. U. z 2015 r., poz. 1242). Wskaźnik korygujący dla płatnika ustalany jest według kategorii ryzyka ustalonej dla danego płatnika.

Ubezpieczenie wypadkowe obejmuje ryzyko zajścia wypadku przy pracy, choroby zawodowej, a także ryzyko wystąpienia wypadku zrównanego z wypadkiem przy pracy. Ustawa przewiduje świadczenia z ubezpieczenia wypadkowego, służące zabezpieczeniu wszystkich skutków doznanego uszkodzenia ciała. Specyfika ubezpieczenia wypadkowego wyraża się również w tym, że w zakresie zdolności do zarobkowania, będącej skutkiem doznanego urazu bądź śmierci, przewiduje świadczenia odszkodowawcze ze względu na doznany trwały bądź stały uszczerbek na zdrowiu (Jędrasik-Jankowska2014: 370). Ubezpieczenie wypadkowe obejmuje zarówno świadczenia krótkoterminowe, jak i te, które związane są z długotrwałą niezdolnością do pracy oraz ze śmiercią żywiciela. 


\section{Publiczne czy prywatne składki na ubezpieczenie społeczne?}

\subsection{Granice pomiędzy normami publicznoprawnymi a prywatnoprawnymi w ubezpieczeniach społecznych}

Przedstawiona charakterystyka składek na ubezpieczenie społeczne nasuwa wątpliwość co do tego, jaki jest charakter (walor) tych składek, czy są one składkami publicznymi, czy też poszczególne zmiany przepisów doprowadziły do pojmowania ich jako prywatnej własności poszczególnych ubezpieczonych, którzy uczestniczą w ich gromadzeniu. Powyższe założenia odnoszą się w szczególności do składek emerytalnych, bowiem tutaj ścierają się dwie tendencje - prawa prywatnego i prawa publicznego, a więc tam, gdzie dochodzi do podziału składki emerytalnej pomiędzy I i II filar.

Przy poszukiwaniu odpowiedzi na tak sformułowaną tezę należy pominąć składki opłacane przez pracodawców, ponieważ w związku z ubruttowieniem wynagrodzenia (o czym była mowa wcześniej) można przyjąć koncepcję, że składka w swej istocie finansowana jest $w$ dalszym ciągu przez pracodawcę, ale $z$ drugiej strony stanowi ona część prawa majątkowego pracownika do wynagrodzenia określonego jako brutto.

Pracodawca pomimo finansowania części składek ubezpieczeniowych nie nabędzie nigdy prawa do świadczenia. Do pracodawcy nie będzie miała zastosowania również składka emerytalna odprowadzana przez członka OFE.

Mówiąc o czymś prywatnym, mamy na myśli powiązanie go z konkretną jednostką, która korzysta z prawa (np. prawa do własności), samodzielnie nim dysponuje, może je nabywać, zbywać, dokonywać różnorakich czynności prawnych. Podmiot ten działa zatem $w$ ramach stosunków cywilnoprawnych, natomiast przymiot publiczny kojarzony jest z państwem jako ogółem, które z jednej strony ma zabezpieczać interesy zbiorowości, a z drugiej zapewniać poszanowanie prawa poszczególnych jednostek, które w jego obrębie funkcjonują. Obywatele funkcjonują na zasadzie swoistego kontraktu z państwem: w zamian za spełnienie obowiązków wobec państwa jednostka uzyskuje gwarancje bezpieczeństwa, i to zarówno w sferze gospodarczej (dla większości związanej z sytuacją wewnętrzną, dającej poczucie stabilizacji), jak i nienaruszalności państwa (wymiar zewnętrzny). Oba te wymiary wymagają niejednokrotne poczynienia nakładów finansowych. Dla systemu publicznego właściwe będą normy należące do systemu prawa publicznego, z kolei dla prywatnego normy należące do prawa prywatnego.

Wszystko to, co jest publiczne, podlega prawu publicznemu w każdym z jego aspektów, natomiast rzecz prywatna na swoje uzasadnienie w prawie prywatnym. Mówiąc o czymś, że jest publiczne, mamy na myśli również i wykonywanie zadań publicznych nałożonych przez państwo, ale też takich, które służą użyteczności publicznej. Temu ma służyć realizacja interesów ogółu (Zieliński 1994: 65). Rzecz publiczna ma służyć używaniu publicznemu i daje możliwość korzystania z niej przez organy administracji 
publicznej w celu realizacji zadań publicznych. Podział ten nie jest jednak sztywny i nie ma charakteru ramowego (Szczepaniak 2013).

Do tej pory nie zostały wypracowane systemy prawne, które w swej metodologii przeprowadziłyby sztywny podział na prawo prywatne i na prawo publiczne. Brak jednolitego podziału powoduje, że często balansuje się na styku tych dwóch dziedzin, nie ma zatem pełnej jasności co do tego, które normy prawa cywilnego będą miały również zastosowanie do prawa publicznego (Szczepaniak 2013). Często stwierdza się, że kryterium prywatnoprawne będzie miało zastosowanie również do regulacji publicznoprawnych, ponieważ jest ono lepiej uregulowanie, a ponadto zostało poddane kodyfikacji. Stosowanie regulacji prywatnoprawnych do prawa publicznego nie napotyka właściwie na większe opory. Stosowanie regulacji cywilnych do stosunków zachodzących pomiędzy podmiotami, z których jeden ma charakter publicznoprawny, w naszym systemie nie jest wyłączone (Szczepaniak 2013).

Prawo ubezpieczeń społecznych jest dziedziną prawa, która opiera się na złożonym przedmiocie regulacji. Mogą być to zmodyfikowane regulacje cywilnoprawne, administracyjnoprawne, ale też i właściwe tylko dla siebie. Występuje tutaj mnogość relacji zachodzących w różnych fazach ubezpieczenia pomiędzy różnymi równorzędnymi podmiotami (Antonów 2008), zatem podział na wskazane powyżej dwie kategorie norm w ubezpieczeniach społecznych nie ma charakteru sztywnego, prowadzącego do stosowania tylko jednej kategorii norm.

\subsection{Rozróżnienie kryterium podziału składek na publiczne i prywatne}

Analiza przepisów w kontekście obowiązku opłacania składki nasuwa stwierdzenie, że składka na ubezpieczenie społeczne nie jest własnością prywatną osoby, która ją wnosi do funduszu, chociaż stanowi osobisty (prywatny) wkład osoby ubezpieczonej z własnego wynagrodzenia (dochodu). Jedynym bodźcem opłacania składek na ubezpieczenia może być perspektywa istnienia ekspektatyw (a więc perspektywa nabycia świadczenia w przyszłości) oraz to, że składka zapisywana jest na indywidualnym koncie ubezpieczonego, funkcjonującym w ramach Funduszu Ubezpieczeń Społecznych.

Stanowisko to nie jest już takie jednoznaczne, gdy mamy do czynienia z podziałem jednej składki emerytalnej przekazywanej w części do Funduszu Ubezpieczeń Społecznych, a w drugiej części do OFE. Problem ten, choć mniej aktualny obecnie, nabierał istotnego znaczenia zwłaszcza w czasie, gdy dokonano przesunięcia aktywów OFE do ZUS - umorzenia 51,5\% jednostek w OFE.

Wątpliwości w tym względzie budzi zwłaszcza charakter środków gromadzonych w funduszu, który składa się również ze składek jego członków. Można zastanowić się nad tym, czy składka do OFE, z jednej strony mająca charakter prywatny, służy realizacji określonych celów publicznoprawnych, czy też z drugiej strony ma ona wymiar publiczny, realizowany przez prawo prywatne i jego instytucje. 
Składka przekazywana do OFE stanowi część składki emerytalnej, która ma wymiar publicznoprawny. Jest to składka przymusowa, odpłatna, celowa i jest nie chroniona przez prawo prawem własności. Na tej podstawie część autorów skłania się ku tezie, że składka, pomimo przekazana jej do OFE, zachowuje wymiar publicznoprawny (Jabłoński, 2013: 48). W takim też ujęciu problem ten rozstrzygnął Sąd Najwyższy (wyrok Sądu Najwyższego z dnia 4 czerwca 2008 r. II UK 12/08).

Wywody sądu oparte zostały na charakterystyce tego poglądu poprzez pryzmat publicznoprawnej konstrukcji stosunku ubezpieczeniowego. Sąd podkreślił jednoznacznie , że składki emerytalne, które są odprowadzone do funduszu, nie są prywatną własnością członka funduszu, a ich źródłem pochodzenia jest przekazanie części składki emerytalnej przez zakład na to ubezpieczenie. Składki przeliczane są na jednostki rozrachunkowe i stanowią podstawę nabycia w przyszłości przez członka funduszu uprawnień cząstkowych do przyszłej emerytury (środków, które są zgromadzone na indywidualnym koncie). Zdaniem sądu o publicznym charakterze składki świadczyć może również i to, że składka emerytalna - z uwagi na jej przeznaczenie na tworzenie funduszu emerytalnego - charakter taki zachowuje nadal po przekazaniu przez zakład jej części do funduszu, ponieważ system ubezpieczeń społecznych posiada wymiar powszechny. Nie został on skonstruowany przez ustawodawcę dla indywidualnych potrzeb ubezpieczonych z uwzględnieniem ich przymiotów osobistych takich jak zaradność, przedsiębiorczość, znajomość reguł rynku kapitałowego, przewidywalność czy przezorność, ale dla ogółu osób, które zostały objęte ubezpieczeniem i w przyszłości staną się beneficjentami powszechnego systemu emerytalnego. W związku z tym realizacja prawa do zabezpieczenia społecznego po osiągnięciu wieku emerytalnego leży w gestii ustawodawcy i do niego należy wybór warunków, jakie winny stanowić podstawę do nabycia prawa podmiotowego (Zieleniecki 2013: 39).

Związane z powyższym jest przeznaczenie składek na cel publiczny będący wynikiem realizacji konstytucyjnej zasady wynikającej z art. 67 ust. 1 Konstytucji, przewidującej nabycia prawa do świadczenia w przyszłości. Państwo ma obowiązek zabezpieczyć swoich obywateli, ma temu służyć ubezpieczenie społeczne i związany z tym przymus opłacania składek przez szeroka grupę osób na to ubezpieczenie (Jabłoński 2013: 48). Ustawodawca nie jest związany do tworzenia formy ubezpieczeniowej przy zabezpieczeniu ryzyka na starość, stąd też dopuszcza się możliwość tworzenia systemów emerytalnych polegających na gromadzeniu kapitałowego pokrycia emerytur przez przymus inwestowania środków pochodzących ze składek (Pacud 2010).

Składka na ubezpieczenie emerytalne przekazana do OFE wchodzi w skład mienia funduszu, nie jest ona zatem ani dotacją, ani też darowizną - stanowi wkład osobisty członka OFE. Pomimo że OFE tworzone przez Powszechne Towarzystwa Emerytalne są instytucjami prywatnymi, ich działalność w zakresie składki emerytalnej ma wymiar publiczny - stają się organami wykonawczymi ubezpieczeń społecznych. Wynika to z podziału części zadań publicznych w zakresie ubezpieczenia społecznego 
i przekazanie ich OFE jako instytucjom niepublicznym. Realizowany wymiar publiczny ubezpieczenia społecznego przez OFE jest silnie akcentowany w związku z nadaniem osobowości prawnej OFE, nie można jednak przypisać tym instytucjom cech publicznych, ponieważ nie są one tworzone z woli i w imieniu państwa.

Przekazanie składek emerytalnych na własność OFE powoduje powstanie po stronie członka OFE roszczenia, którego treścią jest możliwość żądania sfinansowania z tych środków jego emerytur w terminach i na zasadach wskazanych w ustawie. Członek OFE poprzez zawarcie umowy, a następnie wnoszone składki staje się beneficjentem funduszu. Długoletnie uczestnictwo w OFE w tym aspekcie powodować może potencjalne korzyści po stronie członka, będące efektem długoletniej akumulacji środków w funduszu. OFE zarządza zatem zgromadzonymi środkami we własnym imieniu, ale na rzecz i ze skutkiem dla swoich członków, co odpowiada konstrukcji powiernictwa (Jabłoński 2013: 47). Składka po przekazaniu staje się własnością OFE. Członek OFE nie ma prawa do składek ubezpieczeniowych, ale do określonej liczby jednostek rozrachunkowych, wycenianych $w$ trakcie dokonywania obliczania wartości aktywów (Pacud, 2011: 59).

Pogląd o publicznoprawnym charakterze składki na ubezpieczenie emerytalne przeznaczonej do funduszu przejawia się w kwestach technicznych. Sposób przekazania składki do funduszu, procentowe określenie stopy oraz podstawa jej wymiaru czy też wreszcie cel, jakiemu mają służyć, wskazuje, że należy traktować je jako całość, brak jest zatem podstaw, by dokonać rozróżnienia na składkę przekazywaną do FUS i OFE (Zieleniecki 2013: 40).

Charakter składki zmienia się jednak - zdaniem niektórych autorów - po jej przekazaniu przez ZUS do OFE, kiedy to do na plan pierwszy wysuwają się jej elementy prywatnoprawne. Składka zmienia swój charakter publicznoprawny na prywatnoprawny, będąc częścią aktywów prywatnej osoby prawnej, którą jest fundusz (Zieleniecki 2013: 40). W ten sposób składki stają się powiązane prywatnoprawnym segmentem emerytur.

Poglądy o takim charakterze akcentowane są z punktu widzenia uprawnień, jakie posiadają członkowie funduszu, którego członkostwo ma charakter ściśle zindywidualizowany. Za takim ujęciem przemawia koncepcja stanowiąca, że składki ubezpieczonych przekazywane do OFE są składnikiem majątku członka funduszu. Członek funduszu nie wyzbywa się swoich praw z chwilą przekazania składki do OFE, doznaje jedynie pewnych ograniczeń w korzystaniu z prawa władności do składki. W zamian uzyskuje on daleko idące uprawnienia nie tylko do ekspektatywy przyszłej emerytury. Do takich uprawnień należy korzystanie przez członka OFE z:

1) prawa przenoszenia środków do innego funduszu,

2) prawa złożenia dyspozycji przekazania środków na dochody budżetu państwa,

3) prawa żądania informacji o aktualnej pieniężnej wartości środków zgromadzonych na rachunku, 
4) objęcia środków zgromadzonych na rachunku małżeńską wspólnością majątkową

5) prawa do rozrządzenia tymi środkami na wypadek śmierci, a w przypadku braku wskazania osób uposażonych, włączenie tych środków do masy spadkowej (Zieleniecki 2013: 38).

Marcin Zieleniecki wskazuje poglądy prywatnoprawnej koncepcji składki przekazywanej do OFE akcentowaną przez Katarzynę Roszewską (2011). Podstawę do jej sformułowania stanowił m.in. art. 22 ust. 3 ustawy o systemie ubezpieczeń społecznych w brzmieniu obowiązującym do 30 kwietnia 2011 r., który podkreślał, że część składki na ubezpieczenie emerytalne przeznaczona na finansowanie emerytury metodą kapitałową pochodzi ze środków ubezpieczonego. Członek OFE poprzez zapłatę składki do OFE wyzbywa się aktywów z własnego majątku w postaci prawa własności do środków pieniężnych i zamienia je z jednej strony na aktywa osobiste zgromadzone w OFE, stanowiące wierzytelności względem funduszy emerytalnych, a z drugiej strony na aktywa osobiste, będące zaczątkiem przyszłej emerytury. Z punktu widzenia ekonomicznego członek OFE nadal jest właścicielem środków przekazanych do OFE, a z punktu widzenia prawnego jest on wierzycielem OFE, a także posiadaczem ekspektatyw emerytury dożywotniej (Pacud 2006: 108). Przekazane środki do OFE nie mają wymiaru wspólnotowego, ponieważ służą realizacji ekspektatyw poszczególnych członków OFE, a nie całej zbiorowości. Również cel funkcjonowania funduszy jest bardziej indywidualny niż społeczny - zabezpieczenie bytu na starość jego członków.

Koncepcja ta uległa jednak podważeniu w związku z zasadami wprowadzonymi na mocy ustawy z dnia 25 marca 2011 r. o zmianie niektórych ustaw związanych z funkcjonowaniem systemu ubezpieczeń społecznych (Dz. U. z 2011 r. Nr 75, poz. 398, z późn. zm.). Nadała ona nowe brzmienie art. 22 ust. 3 ustawy o systemie ubezpieczeń społecznych, usuwając z niego zapis o pochodzeniu części składki na ubezpieczenie emerytalne ze środków ubezpieczonego. Część składki przeznaczona na finansowanie emerytur metodą kapitałową miała być odtąd przekazywana do FUS i być ewidencjonowana na specjalnie tworzonym subkoncie na indywidualnym koncie emerytalnym. Ubezpieczeni uzyskali uprawnienia, które do tej pory powiązane były z kapitałowym segmentem lokowania środków ubezpieczenia emerytalnego i w związku z tym podważyło to prawo członka funduszu do uczestnictwa w aktywach zgromadzonych w OFE (Zieleniecki 2013: 38).

Mając na względzie powyższe rozważania, należy przychylić się do poglądu, że składka emerytalna wnoszona do otwartego funduszu emerytalnego za pośrednictwem ZUS zachowuje również charakter publicznoprawny. Uzasadnienia tego poglądu należy szukać nie tylko poprzez pryzmat stosunków ubezpieczeniowych, ale przede wszystkim ze względu na cel, jakiemu ma służyć. Funkcjonowanie składki emerytalnej w ramach OFE jest świadomym wyborem ustawodawcy co do przyjętego sposobu finansowania świadczeń emerytalnych. $Z$ drugiej jednak strony zastosowanie metody podziału składki może doprowadzić do całkowitego zerwania elementów solidarnościowej umowy międzypokoleniowej pomiędzy osobami młodszymi i starszymi, 
stanowiącej do tej pory podwaliny całego systemu ubezpieczeń społecznych. Nie bez przyczyny ustawodawca wycofuje się w kolejnych zmianach przepisów z wcześniejszych reform systemu kapitałowego.

Bez względu na to, czy jest to składka wypłacana wyłącznie do FUS, czy też i do OFE, stanowi ona ciężar dla osoby zobowiązanej do jej opłacenia. Realizacja zabezpieczenia społecznego dokonywana jest w oparciu o ciężary publicznoprawne. Holistyczne spojrzenie na charakter prawny składki zgromadzonej w OFE pozwala przyjąć tezę, że składka ta zachowuje cechy publicznoprawne.

Ostatecznie na temat kwestii charakteru składki emerytalnej wypowiedział się Trybunał Konstytucyjny na gruncie oceny zgodności z konstytucją zmian w funkcjonowaniu systemu emerytalnego przewidzianych w reformie z 2013 r (wyrok z dnia 4 listopada 2015 r. - K 1/14). Podzielił on właściwie dotychczasowe zapatrywania co do charakteru składki, potwierdzając jej cechy publicznoprawne. Na te cechy składa się funkcjonowanie składek $w$ obrocie prawnym filarowego systemu emerytalnego, dla funkcjonowania którego mają znaczenie dwa pierwsze filary. Funkcjonowanie tak skonstruowanego systemu stanowi odzwierciedlenie konstytucyjnej zasady zabezpieczenia społecznego, przy czym wybór, w jakim zasada ta będzie funkcjonowała, należy już do ustawodawcy.

Pierwszy filar ma charakter powszechny, obowiązkowy i repartycyjny, natomiast drugi jest powszechny, obowiązkowy i kapitałowy. System jednak nie ma charakteru statycznego, czego wyrazem są liczne zmiany w jego funkcjonowaniu, jakie towarzyszyły kolejnym modyfikacjom zaproponowanej w 1999 r. reformie emerytalnej. Trybunał podkreślił, że środki przekazywane do OFE pochodzą z części składki emerytalnej. Ustawodawca podzielił jedną składkę emerytalną pomiędzy dwa filary. Niepodwyższenie składki emerytalnej spowodowało, że coraz bardziej rozrastał się system kapitałowy wobec napływu kolejnych roczników osób ubezpieczonych kosztem modelu repartycyjnego (umowy międzypokoleniowej), z którego finansowane są obecnie świadczenia.

O publicznoprawnym charakterze składek emerytalnych w ocenie Trybunału świadczy również i to, że ubezpieczony co prawda ma indywidualny rachunek w OFE, podobnie jak na subkoncie w ZUS, jednak nie może on swobodnie dysponować tymi środkami w przeciwieństwie do trzeciego filaru systemu emerytalnego. Składka emerytalna, pomimo silnej personalizacji opartej na indywidualnym koncie ubezpieczonego, nie jest jego własnością.

Nie podlega dyskusji to, że w ramach funkcjonowania funduszy emerytalnych funkcjonują też elementy prywatnoprawne składki, związane z umożliwieniem częściowego dysponowania środkami w innym przypadku niż dożycie wieku emerytalnego. Pobieranie prowizji w postaci opłaty funduszu będącego wynagrodzeniem może świadczyć o tym, że fundusze obok wykonywania zadań publicznych w postaci lokowania składek emerytalnych prowadzą również działalność zarobkową. 
Składki na ubezpieczenie społeczne stanowią cenę gwarancji ubezpieczenia, jaką uzyskuje osoba ubezpieczona, przez wielu postrzegane są jednak jako element polityki fiskalnej państwa, dodatkowy koszt pracy. Stanowią często spory wydatek dla mniejszych przedsiębiorców. Nieopłacalność zatrudniania pracowników powoduje konieczność wepchnięcia ich do grupy podmiotów prowadzących działalność gospodarczą. Wysokość zapłaconych składek nie stanowi często odzwierciedlenia w wysokości późniejszych świadczeń, do tego częste zmiany regulacji prawnych spowodowane dynamizmem prawa ubezpieczeń społecznych powodują negatywne nastawienie osób je opłacających. Nie sprzyja temu rosnąca liczba świadczeniobiorców, stąd też koniecznym staje się poszukiwanie alternatywnych rozwiązań, które mogłyby poprawić ogólne nastawienie społeczne.

Wydaje się, że dobrym rozwiązaniem byłoby uszczelnienie całego systemu składkowego, czyli poszerzenie bazy składkowej poprzez osoby, które aktualnie nie płacą składek ubezpieczeniowych (z uwagi na brak tytułu do ubezpieczenia) albo płacą składki niższe. Z drugiej strony państwo powinno zachęcać do podejmowania działalności gospodarczej poprzez zasadę obniżonej (preferencyjnej) składki (Rzeczpospolita 2017). Dotyczyć to powinno również osób zarabiających najniżej, dla których opłacenie składki na ubezpieczenia i pozostałych danin stanowi spory, bo około $27 \%$ koszt z ich wynagrodzenia (Dziennik Gazeta Prawna, 2016). Różnie podchodzi się do koncepcji stworzenia jednolitej daniny publicznej, która obejmowałaby także składki na ubezpieczenia społeczne, w konsekwencji mogłoby to jednak doprowadzić do zatracania typowych cech składek na ubezpieczenia społeczne w dotychczasowej postaci.

Podjęcie zmian w tym zakresie wymaga wielu konsultacji i analiz, ponieważ nie mogą one stanowić podstawy stworzenia nowych, niekorzystnych społecznie zjawisk.

\section{Literatura}

Antonów K., 2008, Glosa do wyroku SN z dnia 4 czerwca 2008 r., II UK 12/08. Ubezpieczenie emerytalne - charakter prawny składki odprowadzanej do OFE - obowiązek zawarcia umowy z OFE ,",Orzecznictwo Sądów Polskich" 2009 nr 6.

Bielawska K., 2013, Ubezpieczenia emerytalne. Reforma systemu ubezpieczeń emerytalnych (w:) Ubezpieczenia, red. M. Iwanicz-Drozdowska, Warszawa: Polskie Wydawnictwo Ekonomiczne.

Cichosz E., 2013, Ubezpieczenia rentowe (w:) Ubezpieczenia, red. M. Iwanicz-Drozdowska, Warszawa: Polskie Wydawnictwo Ekonomiczne.

Dziennik Gazeta Prawna, 2016, Jedna danina zamiast PIT oraz składek na NFZ i ZUS, „,Dziennik Gazeta Prawna" 14.03.2016.

Golinowska S., 2014, Funkcje państwa w zabezpieczaniu dochodów na okres starości. Zmiana warunków i paradygmatów na przykładzie polskiej reformy systemu emerytalnego (w:) Ubezpieczenia społeczne w procesie zmian: 80 lat Zakładu Ubezpieczeń Społecznych, red. K.W. Frieske, E. Przychodaj, Warszawa: Zakład Ubezpieczeń Społecznych, Instytut Pracy i Spraw Socjalnych.

Iwanicz-Drozdowska M. (red.), 2013, Ubezpieczenia, Warszawa: Polskie Wydawnictwo Ekonomiczne. 
Jabłoński A.,2013, Konstytycyjno-prawna ocena zmian w sytuacji prawnej OFE, członków OFE i PTE (w:) Prawne mechanizmy przekazywania środków OFE. Oceny konstytucyjno-prawne, Kraków: Oficyna Allerhanda.

Jackowiak C., 1964, Prawo pracy, t. 2, cz. 2, Poznań: PWN.

Jackowski M., Zalasiński T., 2013, Przymusowe umorzenie 51\% aktywów OFE. Problem jednorazowego umorzenia aktywów w OFE w świetle orzecznictwa TK (w:) Prawne mechanizmy przekazywania środków OFE. Oceny konstytucyjno-prawne, Kraków: Oficyna Allerhanda.

Jaroszek P., 2014, Zarządzanie finansami ubezpieczeń społecznych (w:) Ubezpieczenia społeczne w procesie zmian: 80 lat Zakładu Ubezpieczeń Społecznych, red. W. Frieske, E. Przychodaj, Warszawa: Zakład Ubezpieczeń Społecznych, Instytut Pracy i Spraw Socjalnych.

Jędrasik-Jankowska I., 2001, Ubezpieczenie emerytalne. Trzy filary, Warszawa: Wydawnictwo Prawnicze PWN.

Jędrasik-Jankowska I., 2014, Pojęcia i konstrukcje prawne ubezpieczenia społecznego, Warszawa: Wolters Kluwer.

Jończyk J., 2003, Prawo zabezpieczenia społecznego. Ubezpieczenia społeczne i zdrowotne bezrobocie i pomoc społeczna, Kraków: Zakamycze.

Jończyk J., 2007, Składka na ubezpieczenie zdrowotne „Praca i Zabezpieczenie Społeczne”, nr 8.

Kitala D., 2013, Organizacja systemu ubezpieczeń społecznych, (w:) Ubezpieczenia, red. M. Iwanicz-Drozdowska, Warszawa: Polskie Wydawnictwo Ekonomiczne.

Klimas M., 2013, Postępowanie sq̨dowe z zakresu ubezpieczeń społecznych, Warszawa: Wolters Kluwer Lach D.E., 2010, Komentarz do art. 27 ustawy o ubezpieczeniu społecznym z tytułu wypadków przy pracy i chorób zawodowych (w:) D.E. Lach, S. Samol, K. Ślebzak, Ustawa o ubezpieczeniu społecznym z tytułu wypadków przy pracy i chorób zawodowych, Warszawa: Wolters Kluwer

Modliński E., 1968, Podstawowe zagadnienia prawne ubezpieczeń społecznych, Warszawa: Wydawnictwo Prawnicze.

Olszewska M., 2013, Zakres przedmiotowy ubezpieczenia społecznego (w:) Ubezpieczenie społeczne dawniej i dziś w 80-lecie uchwalenia ustawy o ubezpieczeniu społecznym, Wrocław: Zakład Ubezpieczeń Społecznych, Instytut Pracy i Spraw Socjalnych.

Pacud R., 2006, Oczekiwanie prawne na emeryturę dożywotniq̨. II filar, Bydgoszcz-Katowice: Branta.

Pacud R., Glosa do wyroku SN z dnia 4 czerwca 2008 r., II UK 12/08. Obowiqzek uczestnictwa w otwartym funduszu emerytalnym - charakter prawny składki przekazywanej do OFE - oszczędzanie przymusowe w OFE a konstytucyjna ochrona własności, Orzecznictwo Sądów Polskich” 2010, nr 10.

Pacud R., 2011, Stosunki prawne ubezpieczenia emerytalnego, Warszawa: Wolters Kluwer.

Pacud R. (red.), 2014, Prawne mechanizmy przekazywania środków OFE, Kraków: Oficyna Allerhanda. Piotrowski J., 1966, Zabezpieczenie społeczne. Problematyka i metody, Warszawa: Książka i Wiedza.

Roszewska K., 2011, Tytuł prawny do składki w OFE (w:) Współczesne problemy prawa pracy i ubezpieczeń społecznych, red. L. Florek, Ł. Pisarczyk, Warszawa: Lexis Nexis.

Rzeczpospolita, 2017, Jednolity - reaktywacja? „Rzeczpospolita” 17.01.2017.

Sanetra W., 2014, Aksjologiczne podstawy prawa ubezpieczeń społecznych (w:) Ubezpieczenia społeczne w procesie zmian: 80 lat Zakładu Ubezpieczeń Społecznych, red. W. Frieske, E. Przychodaj, Warszawa: Zakład Ubezpieczeń Społecznych, Instytut Pracy i Spraw Socjalnych.

Sektor funduszy emerytalnych w Polsce - ewolucja, kształt, perspektywy, 2016, Urząd Komisji Nadzoru Finansowego, www.knf.gov.pl/Images/Sektor_funduszy_emerytalnych_w_Polsce_2016_tcm7547307.pdf [dostęp: 28.09.2016]. 
Składka na ubezpieczenie emerytalne, www.mpips.gov.pl/ubezpieczenia-spoleczne/ ubezpieczenie-emerytalne/skladka-na-ubezpieczenie-emerytalne/

www.zus.pl/default.asp?p=4\&id=3387 [dostęp 28.09.2016].

Szubert W., 1973, Studia z polityki społecznej, Warszawa: Państwowe Wydawnictwo Ekonomiczne.

Szubert W., 1987, Ubezpieczenie społeczne. Zarys systemu, Warszawa: PWN.

Ślebzak K., 2013, Prawny charakter składek na ubezpieczenie społeczne (w:) Ubezpieczenie społeczne dawniej i dziś w 80-lecie uchwalenia ustawy o ubezpieczeniu społecznym, Wrocław: Zakład Ubezpieczeń Społecznych, Instytut Pracy i Spraw Socjalnych.

Szczepaniak R., 2013, Sens i nonsens podziału na prawo publiczne i prywatne w kontekście uchwały Sądu Najwyższego, "Państwo i Prawo” nr 5,

Uziak W., 2009, Wskaźnik waloryzacji (w:) Leksykon prawa ubezpieczeń społecznych. 100 podstawowych pojęć, red. A Wypych-Żywicka, Warszawa: C.H. Beck.

Wajda D., 2011, Komentarz do art. 22 ustawy o systemie ubezpieczeń społecznych (w:) Ustawa o systemie ubezpieczeń społecznych, red. B. Gudowska, J. Strusińska-Żukowska, Warszawa: C.H. Beck.

Wantoch-Rekowski J., 2005, Składki na ubezpieczenia emerytalne, Toruń: TNOiK.

Wantoch-Rekowski J., 2014, System ubezpieczeń społecznych a budżet państwa. Studium prawno finansowe, Warszawa: Wolters Kluwer.

Wantoch-Rekowski (red.), 2015, Podstawy prawa finansów ubezpieczeń społecznych, Toruń: TNOiK. Wyrok z dnia 4 czerwca 2008 r. II UK 12/08, http://www.sn.pl/sites/orzecznictwo/Orzeczenia1/II\%20 UK\%2012-08-1.pdf [dostęp: 28.09.2016].

Wyrok z dnia 3 lutego 2012 r. I UK 306/11

http://www.sn.pl/sites/orzecznictwo/Orzeczenia2//\%20UK\%20306-11-1.pdf [dostęp: 28.09.2016].

Zieleniecki M., 2011, Emerytura pomostowa w nowym systemie emerytalnym, Gdańsk: Fundacja Rozwoju Uniwersytetu Gdańskiego.

Zieleniecki M., 2013, Dopuszczalność obligatoryjnego umorzenia 51,5\% jednostek rozrachunkowych w OFE. Kryteria oceny, rozbieżności doktryny, warianty (w:) Prawne mechanizmy przekazywania środków OFE. Oceny konstytucyjno-prawne Kraków

Zieliński T., 1994, Ubezpieczenia społeczne pracowników: Zarys wykładu, Kraków: PWN.

Żukowski M., 2014, Ekonomiczne aspekty ubezpieczeń społecznych (w:) Ubezpieczenia społeczne w procesie zmian: 80 lat Zakładu Ubezpieczeń Społecznych, red. K.W. Frieske, E. Przychodaj, Warszawa:Zakład Ubezpieczeń Społecznych, Instytut Pracy i Spraw Socjalnych. 